\title{
RAVENS AND OTHER RAPTORS OCCUPY WINTER ROOSTS WITH BALD EAGLES IN UTAH
}

\author{
Bryan T. Brown ${ }^{1,2}$, Dana G. Truman ${ }^{1,3}$, Linda Jones ${ }^{1}$, and Thomas Sharp ${ }^{1}$
}

Key words: Bald Eagle, winter roosts, Common Raven, hawks, interspecific mutualism, Utah.

Bald Eagles (Haliaeetus leucocephalus) often roost communally at night during winter. Roost sites, which typically occur in the largest and tallest trees in an area, may be occupied by eagles every night and are traditionally used year after year (e.g., Stalmaster 1987, Palmer 1988, Buehler 2000). Anecdotal accounts by Palmer (1988:226) describe Common Ravens (Corvus corax) and other raptors, including Golden Eagles (Aquila chrysaetos), roosting with Bald Eagles during winter. Steenhof (1984) reported that Ferruginous Hawks (Buteo regalis) roosted with Bald Eagles during winter in South Dakota, while Smith and Murphy (1978) reported that Ferruginous Hawks avoided roosting with Bald Eagles during winter in Utah. Despite the large volume of published material on eagle winter roosts and roosting behavior, little systematic information on interspecific use of Bald Eagle roosts is available. This void may exist because interspecific use of roosts rarely occurs, although more likely is that investigators observe but typically do not report the behavior. For example, Common Ravens were occasionally observed roosting with Bald Eagles in a northern Utah study, yet the behavior was not reported (Wilson and Gessaman 2003, Robert Wilson personal communication). Here we document the behavior and frequency of ravens and other raptors occurring in Bald Eagle winter roosts in northern Utah and speculate on possible causes.

The study area was a $22-\mathrm{km}$ corridor adjacent to the southeastern shore of the Great Salt Lake in northern Utah between I-215 in northern Salt Lake County and the town of Farmington in Davis County. The terrain was flat (elevation $1285 \mathrm{~m}$ ) and was dominated by open farmlands and wetlands bisected by small streams, canals, and ponds. Trees were relatively uncommon and, when present, consisted primarily of cottonwood (Populus spp.), willow (Salix spp.), and Russian olive (Eleagnus angustifolia) in discrete stands. Scattered rural and suburban residences, commercial developments, electrical transmission lines, and industrial sites occurred throughout. The Jordan River delta was located in the southern portion of the area.

Abundance of Bald Eagles and abundance and frequency of ravens and other raptors were determined using counts at 7 eagle winter roosts adjacent to the shore of the Great Salt Lake. Birds at the roosts were counted on 2 evenings per week from 1 November 2001 through 28 March 2002 (all 7 roosts were visited on the same evenings). Counts occurred continuously from about 15 minutes before sunset until dark; ravens and raptors present at last light were assumed to remain there for the night. Observers used 10X binoculars and 15-45X spotting scopes and conducted counts from vehicles located about $100-600 \mathrm{~m}$ from roosts, depending upon access, to minimize potential disturbance to Bald Eagles. One roost was anomalous because it was located $<100 \mathrm{~m}$ from suburban development and paved roads receiving moderate use; we observed the roost from a vehicle parked on the road without apparent disturbance to eagles.

The following parameters were recorded: number of Bald Eagles present, species and numbers of ravens and other raptors present (if any), distances from those birds to the nearest eagles, and behavioral interactions between eagles and ravens or other raptors. We included 
only ravens and other raptors located $\leq 100 \mathrm{~m}$ from roosting eagles; $100 \mathrm{~m}$ was chosen because existing cottonwood and willow stands did not exceed $200 \mathrm{~m}$ in length and because eagles typically roosted together while ravens and other raptors roosted throughout the stands. Distances from ravens and other raptors to roosting eagles were visually estimated to the nearest $5 \mathrm{~m}$. Means of response variables are reported with 1 standard deviation $( \pm s)$.

A total of 280 roost counts were conducted. No Bald Eagles were present during 118 counts, and $16 \pm 20$ eagles per count (range 1-105) were detected during 162 counts when eagles were present. Thirty-six individuals of ravens or other raptor species were detected during 17 counts: 8 individuals during 4 counts when no eagles were present and 28 during 13 counts when eagles were present. Overall, ravens and other raptors were present during $6 \%$ of total roost counts, $3 \%$ of counts when no eagles were present, and $8 \%$ of counts when eagles were present.

Ravens and other raptors averaged $2.1 \pm 1.4$ birds per count (range 1-6) when present. Other raptors detected most often in eagle roosts were unknown hawks (Accipitridae; 13 total individuals in 8 counts, range 1-3 per count), followed by Rough-legged Hawks (Buteo lagopus; 12 in 5 counts, range $1-4$ per count), Common Ravens (9 in 2 counts, range 3-6 per count), and Red-tailed Hawks (B. jamaicensis; 2 in 2 counts). Ravens and other raptors were detected most often in January $(n=16$ individuals), followed by February $(n=12)$ and March $(n=8)$ with none detected in November and December.

Ravens and other raptor species roosted 58 $\pm 40 \mathrm{~m}$ from Bald Eagles (range 5-100 m, $n=$ 10). The 2 closest associations occurred when 2 Rough-legged Hawks roosted about $5 \mathrm{~m}$ from 6 eagles in a cottonwood stand and again when a group of 6 Common Ravens roosted about $5 \mathrm{~m}$ from, and on the same branch as, 7 eagles in a large (20-m-tall) willow (Salix sp.). Aggressive interactions did not occur between those birds and the eagles in either instance.

The only instance of apparent aggressive interaction between eagles and ravens or other raptors occurred when 4 Rough-legged Hawks roosting in a stand of mature cottonwoods were joined by 7 eagles. The 2 nd eagle that entered the roost was an adult who flew within $5 \mathrm{~m}$ of 2 of the hawks, extending its wings and noticeably exposing its talons toward the hawks as it passed before settling on the roost. The 2 hawks left immediately, circled the roost area, and returned within about 2 minutes. The other 2 hawks never left the roost.

Ravens and hawks roosting with eagles typically occurred on smaller, more closely spaced, midcanopy limbs, while eagles usually occurred on larger, well-separated limbs higher in the canopy. Ravens and hawks could have been limited to these apparently subordinate microsites within roosts because eagles were dominant but could have gained some advantage from interspecific association. However, ravens and hawks would be expected to always roost with eagles if this theoretical advantage were substantial. Our observations indicated this was not the case because (1) we frequently observed solitary and communal roosting by ravens and other raptors in both trees and electrical transmission poles and towers away from eagle roosts $(\leq 0.5 \mathrm{~km})$ and $(2)$ eagle roosts were usually occupied only by eagles. Alternatively, ravens and other raptors may have used smaller, more closely spaced midcanopy limbs to avoid potential persecution by eagles.

Other raptor species, primarily unknown hawks and Rough-legged Hawks, occurred regularly but uncommonly at eagle roosts. Palmer (1988) reported that Rough-legged Hawks will often roost communally with other raptors in areas of apparent high prey density. Other advantages of ravens and other raptors roosting with eagles include the potential thermal advantage of roosting trees and protection from prevailing winter winds (Stalmaster and Gessaman 1984). However, the latter advantage has been reported only for eagles roosting in conifers. Eagles in our study area roosted in deciduous trees.

Trees of adequate size for roosting in areas of lower human activity were uncommon in the study area, and it is possible that roost sites were a limiting factor. If so, the availability of roost sites may have influenced multispecies use. Eagles used only stands of larger trees for roosting; in contrast, ravens and other raptors were more generalistic in their roostsite use. Although we made casual observations of ravens and other raptors roosting at sites other than traditional eagle roosts, our data did not allow comparison of preference for or discrimination against eagle roost sites versus other potential roost sites. 
Our findings show that (1) ravens and other raptors roosted at night with wintering Bald Eagles more often than the existing literature suggests and (2) caution should be exercised when conducting eagle counts at winter roosts due to the possibility of mistaking ravens and other raptors for Bald Eagles at long distances. Substantial plumage and size differences between taxa would suggest that such misidentification is unlikely. However, field conditions (e.g., lighting at dusk, poor weather, or foliage partially obscuring individuals), distances at which eagle roost counts are typically conducted (occasionally as far as $600 \mathrm{~m}$ ), and our personal observations suggested otherwise. Species and use patterns of ravens and other raptors occupying Bald Eagle winter roosts may vary predictably between geographic regions; additional information on this behavior could provide new perspectives on potential interspecific mutualism in raptor biology.

Funding was provided by Flour-AmesKramer (FAK), L.L.C., and the Utah Department of Transportation (UDOT) as partial mitigation and monitoring required for construction of the Legacy Parkway Project. These findings do not reflect the opinion of FAK, UDOT, or any of its employees and contractors. We thank Dave Holland of SWCA and
Bob Walters of the Utah Division of Wildlife Resources for their encouragement and support. L. Bennett, C. Ellsworth, S. Hatch, R. Robinson, and R. Young assisted with field observations. James Bednarz, James Gessaman, Jocelyn Hudon, and Clayton White commented on an early draft of this manuscript.

\section{Literature Cited}

Buehler, D.A. 2000. Bald Eagle (Haliaeetus leucocephalus). In: A. Poole and F. Gills, editors, The birds of North America, no. 506. The Birds of North America, Inc., Philadelphia, PA.

Palmer, R.S. (EDITOR). 1988. Handbook of North American birds. Volume 4. Yale University Press, New Haven, CT.

Smith D.G., AND J.R. Murphy. 1978. Biology of the Ferruginous Hawk in central Utah. Sociobiology 3:79-98.

Stalmaster, M.V. 1987. The Bald Eagle. Universe Books, New York.

Stalmaster, M.V., and J.A. Gessaman. 1984. Ecological energetics and foraging behavior of overwintering Bald Eagles. Ecological Monographs 54:407-428.

Steenhof, K. 1984. Use of an interspecific communal roost by wintering Ferruginous Hawks. Wilson Bulletin 96:137-138.

Wilson, R., and J.A. Gessaman. 2003. Two large Bald Eagle communal roosts in Utah. Journal of Raptor Research 37:78-83.

Received 18 February 2005 Accepted 3 November 2005 